\title{
In vitro and Field Efficacy of Native Biocontrol Agents on Stem Bleeding Pathogen of Coconut Thielaviopsis paradoxa
}

\author{
K. Aruna ${ }^{1 *}$ and Kalpana Motha ${ }^{2}$ \\ ${ }^{1}$ Department of Microbiology, A.S.D Govt. Degree College for Women Kakinada- 533101, \\ Andhra Pradesh, India \\ ${ }^{2}$ Horticultural Research Station, DrYSR Horticultural University, Vijayarai-533475, Andhra \\ Pradesh, India \\ *Corresponding author
}

\section{Ke ywords \\ In vitro antagonism, Trichoderma spp, P.fluorescens Coconut pathogens \\ Article Info \\ Accepted: \\ 15 February 2020 \\ Available Online: \\ 10 March 2020}

\section{A B S T R A C T}

Stem bleeding disease caused by Thielaviopsis paradoxa is one of the major diseases of coconut in almost all the coconut growing regions of Andhra Pradesh. Bioefficacy of native bioagents viz., Trichoderma spp and Pseudomonas fluroscens on stem bleeding pathogen Thielaviopsis paradoxa under in vitro conditions revealed that all the three isolated native Trichoderma spp were found inhibitory to the mycelia growth of Thielaviopsis paradoxa on Potato Dexose Agar media. Maximum percent inhibition of mycelia growth of Thielaviopsis.paradoxa was obtained by Trichoderma viride $(69.35 \%)$ followed by Pseudomonas fluroscence to $69.32 \%$ as against only $62.90 \%$ growth inhibition of Thielaviopsis paradoxa by Trichoderma harzianum. Twelve substrates tested for mass multiplication of biocontrol agents viz., T.viride, T.harzianum and T.hamatum under in vitro conditions noticed that maximum mycelial growth of Trichoderma spp was found on $30 \%$ neem cake and $7 \%$ neem cake. Evaluation of native biogents under field conditions revealed that among the eleven treatments imposed, maximum decrease in bleeding patch $\left(13.11 \mathrm{~cm}\right.$ ) was obtained with $\mathrm{T}_{8}$ i.e., basal application of T. harzianum (50 g) + neemcake $(5 \mathrm{~kg}) /$ year $)+$ smearing of talc formulation of T.harzianum paste on stem bleeding patches) closely followed by $\mathrm{T}_{7}$ treatment $(11.55 \mathrm{~cm})$ i.e., basal application of $T$. viride $(50 \mathrm{~g})+$ neemcake $(5 \mathrm{~kg}) /$ year $)+$ smearing of talc formulation of $T$. viride paste on stem bleeding patches) and $\mathrm{T}_{9}$ treatment i.e., basal application of T.hamatum $(50 \mathrm{~g})+$ neemcake $(5 \mathrm{~kg}) /$ year $)+$ smearing of talc formulation of T.hamatum paste on stem bleeding patches) with a reduction in perimeter by $11.55 \mathrm{~cm}$ and $8.51 \mathrm{~cm}$ respectively. On the other hand, un treated control palms showed an increase of $2.68 \mathrm{~cm}$ of perimeter of the bleeding patch. Thus, soil application of Trichoderma spp. along with neem cake and smearing of Trichoderma spp paste to the stem bleeding patches was effective in controlling the stem bleeding disease under field condition. 


\section{Introduction}

Stem bleeding of coconut is a debilitating disease and is prevalent in all coconut growing regions in the tropics. The disease was first reported from Srilanka (Petch, 1906) and later reported in India (Sundararaman, 1922) and other countries. The disease is caused by a fungal pathogen, Thielaviopsis paradoxa (de Seynes) von Hohnel. The disease has been found to occur in all soil types, but more in laterite soils and sandy soils on the seashore or backwater areas (Nambiar, 1994). Stem bleeding disease on coconut recorded up to $15 \%$ in Andhra Pradesh (Srinivasulu et al., 2005). The pathogen is a soil borne pathogen and enters the plant through growth cracks present on the stem and causes cortical decay. The disease is characterized by development of dark brown patches appearing at the basal portion of the trunk. A dark reddish brown liquid exudes from the longitudinal growth cracks present on the stem bark and form irregular streaks of exudation. These streaks may coalesce and form larger lesions. No oozing is seen from old lesions. The exudates eventually dry up to form black encrustations with brownish orange margins. The tissues beneath the discolored patch show decay. As the decay progresses, the tissues become black and fibrous. As a result of this, cavities are formed from which liquid comes out, when the bark is pressed. Severe infection may lead to reduced yield and death of young palms. Symptoms also occur on crown region. The outer whorl of leaves becomes yellow rather prematurely, droop and finally dry up. The trunk gradually tapers towards the apex and the crown size is reduced. The bleeding patches spread spirally about half way up the stem and sometime reach the crown and cause the death of palms. In severe cases the bleeding patches reach the crown and kill the palm.
Soil drenching with calixin $0.1 \%$ (Radhakrishnan, 1990) and root feeding with Bavistin 5\% or Calixin 5\% (Ramanujam et al, 1993), have been found to reduce the disease to some extent. Sudarshan et al.(2019) reported that Difenoconazole 25\% EC @ 0.1\%,Propiconazole 25\% EC@0.1\%, Tebuconazole 25.9\% EC @ $0.15 \%$ and Thiophanate Methyl 70\%WP @ 0.28\% has recorded cent per cent inhibition. Though chemical treatments inhibit the pathogen, but biological control is an eco-friendly, longlasting, highly effective method for the elimination of soil borne pathogens and a good alternative for the chemical and physical treatments. The literature revealed that the pathogen can be successfully controlled by Trichoderma viride under in vitro conditions (Jayaratne et al., 2015; Ranjana Chakrabarty et al., 2013; Tapwal1 et al., 2011).

Several authors reported about the soil application of neem cake will reduce the intensity of pathogen (Kartikeyan et al., 2005; Hoitink et al., 2006; Darmono and Purwantara, 2006). But there is very sparse literature on field efficacy of native bioagents in control of stem bleeding disease in coconut. The present study was carried out to investigate the role of bioagents in inhibiting the growth of the fungus in in vitro and field condition in controlling the disease.

\section{Materials and Methods}

\section{Isolation of coconut pathogens}

The disease symptom of stem bleeding caused by Thielaviopsis paradoxa is depicted in Plate 1. The stem portion of the infected palm where bleeding symptoms were conspicuous was chiseled out and surface sterilized with $0.1 \%$ sodium hypochlorite followed by 3 washes in sterilized distilled water (SDW) and then the stem bits were plated on Potato Dextrose Agar (PDA) media plates for 
Thielaviopsis paradoxa. The plates were then incubated for three days at $29+10 \mathrm{c}$ and the test pathogen was isolated by purification .

\section{Isolation and identification of antagonistic fungi from rhizospheric region of coconut}

Soil samples were collected from rhizospheric region of coconut in Iragavaram and Undaraivaram mandals of West Godavari district, Andhra Pradesh. Serial dilution and plate count method was used for isolation of antagonistic fungi. The collected soil samples were subjected to serial dilutions using sterile distilled water and $0.5 \mathrm{ml}$ of each sample at $10^{-3}$ and $10^{-4}$ dilutions were spread on petridishes containing Trichoderma specific medium (TSM) (Elad and Chet, 1983). Two plates were maintained for each dilution. The plates were then incubated at $28^{\circ} \mathrm{C}$ and were examined after four days. Hyphal tip method was adopted for pure culture of organisms. The isolated antagonistic fungi were identified up to the level of genus or species based of growth, color, philides characters on PDA medium.

\section{Isolation and identification of antagonistic bacteria}

Samples were serially diluted and $0.1 \mathrm{ml}$ of sample was spread on plates containing King's B medium. The isolate was purified by streaking and was maintained further. Identification of bacterial bioagent was made as per the description and physiological status suggested by Hilderband et al., (1992) and identified as Pseudomonas fluroscence.

\section{In vitro antagonism on fungal pathogens of coconut}

Dual cultures of the fungal antagonists and the test pathogen were prepared by inoculating PDA discs from the growing margins of fresh fungal cultures on to petri dishes containing PDA (Gams et al., 1980) and incubating them .The dual cultures were observed for antibiosis and agar blocks from the regions where the colonies merged were observed for typical interactions under the light microscope.

In case of bacterial antagonists, $8 \mathrm{~mm}$ mycelia discs of the pathogens were placed individually at the center of the plates and bacterial strain was streaked at three positions $2 \mathrm{~cm}$ away from edge of the petri plates with PDA medium and incubated. The mycelia growths of the test pathogens were measured at $48 \mathrm{hrs}$ and subsequently one week after incubation (Nandakumar et al., 2000).

Mycoparasitism of test pathogen isolates by fungal antagonists was studied using the dual culture technique developed by Dennis and Webster (1971) described by Sanchez et al., 2007. The antagonists were grown on PDA for a period from 0 to 25 days and their effect on growth of test pathogens were tested by exposing inverted plates of freshly inoculated pathogens to plates containing antagonists cultures and sealing together by cello tape. The pathogen growth was measure after 4 days of incubation in both the cases at $29 \pm$ $1^{\circ} \mathrm{c}$ and percent inhibition was calculated by using the formula as given by Vincent (1947).

$\%$ inhibition $=$

Mean growth in control -
Mean growth in treatment
Mean growth in control 100

\section{Mass multiplication of Trichoderma spp}

The antagonistic fungi viz., T.viride, T.harzianum and T.hamatum, were tested for mass multiplication on coconut leaf bits, coconut coir, coconut dry leaf powder, oil palm stem bits, oil palm leaf bits, farm yard manure, redgram, bajra, bengal gram, wheat 
grain, $30 \%$ neem cake and $7 \%$ neem cake. One hundred gram of each substrate was weighed in conical flasks $(500 \mathrm{ml})$ containing $2 \%$ sucrose solution and kept undisturbed for 24 hours. Later, the excess water was drained out and the flasks were autoclaved and subsequently seeded with mycelial bits of Trichoderma spp. The flasks were then incubated at $28 \pm 1^{\circ} \mathrm{c}$ for 7 days and the observations were recorded.

\section{Assessment of Trichoderma spp population in neemcake}

One gram of sample from developed talc formulation in neemcake was derived at regular intervals and the population (CFU) of Trichoderma spp. in neemcake were conducted at 10, 20, 30, 40, 50, and 60 days intervals after preparation by serial dilution plate technique in selective media for bioagents.

\section{Talc formulation of Trichoderma spp}

Talc formulation of native Trichoderma spp was prepared. Potato dextrose broth was prepared and sterilized by autoclaving at 15 PSI $\left(121.6^{\circ} \mathrm{c}\right)$ for 15 minutes. Eight $\mathrm{mm}$ diameter mycelial discs of antagonist was inoculated and incubated at $28 \pm 1^{\circ} \mathrm{c}$ for 7 days. The homogenate $\left(1 \times 10^{8}\right.$ spores $\left./ \mathrm{ml}\right)$ was mixed with talc powder at $1: 2$ ratio along with $0.5 \%$ carboxy methyl cellulose and dried in shade, following the method described by Jayarajan et al., (1994) with slight modification. The product was used for soil application studies.

\section{Field evaluation of native Trichoderma spp.}

A field experiment was conducted at Iragavaram village, West Godavari district of Andhra Pradesh during 2014 to 2016 for two years, by imposing ten treatments along with untreated control in coconut cultivar East
Coast Tall. The palms were well managed with regular package of practices given by DrYSRHU, Venkaramannagudem. Ten treatments were imposed along with untreated control in Randomized Block Design with three replications and three palms per replication.

Treatment details were given in Table 1.

The talc powder formulations of the bioagents contained a spore load of $625 \times 10^{3} \mathrm{cfu} \mathrm{g}^{-1}$ powder was used for study. Treatments containing basal application of either neem cake alone or in combination with Trichoderma spp were imposed by making basins at a diameter of $2 \mathrm{~m}$ from the stem at a depth of $15 \mathrm{~cm}$ and were immediately covered with soil and irrigated. Talc formulations were also smeared on the bleeding patches. Bleeding patches of nearly equal size were selected for the palms and perimeter of the bleeding patches was taken into account for judging the degree of disease incidence and one conspicuous bleeding patch was selected for each palm imposing treatments on the stem keeping in view the chances of appearance of more than one bleeding patch on the same stem. Initial perimeter on the bleeding patches was recorded prior to imposing the treatments and subsequent observations were made at monthly intervals. The efficacy of the treatments was determined by comparing the reduction in the perimeter of the bleeding patch after recording the final observations after 12 months.

\section{Results and Discussion}

\section{Isolation of coconut pathogens}

Isolation carried out from the diseased tissues yielded a pathogenic isolate of Thielaviopsis paradoxa (Plate 1). The hyphae were pale brown with cylindrical to oval endoconodia. Chalamydospore production is terminal, in 
chain and they are thick walled, obovate to oval, p. palmivira mycelium is typical nonseptate and hyaline, intercellular in the tissue drawing its nutrients through haustoria. It develops rapidly to cover the host tissue with a cottony growth, especially during highly humid condition (Plate 2). The sporangiophores are simple or branched and the sporangia are pear-shaped, with prominent papillae. They are formed singly at the tips of conidiophores, and are hyaline and thin walled, measuring 38-72 x 33-42 $\mu$. They germinate by releasing motile zoospores through the papillary opening.

\section{In vitro antagonism of Trichoderma spp and Pseudonomas fluroscence on coconut stem bleeding pathogens}

The results on in vitro antagonism of biocontrol agents on coconut stem bleeding disease pathogen Thielaviopsis paradoxa (Fig 1) revealed that the percent inhibition of Thielaviopsis paradoxa ranged from 62.90 to $69.35 \%$. It was observed that significantly maximum growth inhibition of Thielaviopsis paradoxa were observed with Trichoderma viride to a percent inhibition of 69.35 followed by Pseudomonas fluroscence to $69.32 \%$ (Plate 3a \& Plate 3b).The least growth inhibition of Thielaviopsis paradoxa to $62.90 \%$ was observed with Trichoderma harzianum. The results are in corroboration with earlier workers who reported the potential of biocontrol agent against coconut pathogens (Jayaratne et al., 2015; Tapwal1 et al., 2011). Sudarshan et al., 2019 reported that Trichoderma viridae was found to be most effective on Thielaviopsis paradoxa with $61.62 \%$ inhibition followed by $T$. harzianum and T. virens with 60.80 and 59.49 per cent inhibition respectively. Trichoderma viridae produces several groups of antibiotics, toxins and then the growth of the pathogen is inhibited (Eziashi et al., 2010). Also it can inhibit or reduce the growth of the pathogen through competition for space, nutrients or oxygen. Priya et al., 2012 reported Pseudomonas fluroscene, a potential inhibitory biocontrol agent against Gnanoderma under in vitro conditions. The inhibition of mycelial growth of the pathogen by Pseudomonas fluroscence may be due to the production of antibiotics. Production of antibiotics $\mathrm{HCN}$, pyrrolnitrin, phenazine and 2, 4-diacetyl phloroglucinol and lytic enzymes by Pseudomonas fluroscence against fungal pathogens were reported by many workers (Ramamoorthy et al 2002; Saravanakumar et al., 2008).

\section{Substrate for mass multiplication of Trichoderma spp}

Twelve substrates were tested for mass multiplication of biocontrol agents viz., Trichoderma viride, T.harzianum and T.hamatum (Table-2). Among the substrates tested, maximum mycelial growth of Trichoderma spp. was found on $30 \%$ neem cake, $7 \%$ neem cake, oil palm stem bits, oil palm leaf bits and wheat grains followed by FYM and coconut fresh leaf bits. However, slight mycelial growth of Trichoderma spp was recorded on redgram and bajra, whereas no mycelial growth was noted on coconut coir and coconut dry leaf powder. The results were in tune with the findings of Bhasakaran, 1990, Mohiddin et al., 2017,). Rini and Sulochana (2007) reported that pre-boiled sorghum grains, coir pith + neem cake $(1: 1)$, cow dung + neem cake $(1: 1)+$ wheat flour $(10 \%)$ maintained high populations of $T$. harzianum and $T$. viride within 10 days of inoculation. Ajay Tomer et al., (2016) noticed very high level of population dynamics and quite longer shelf life of T. harzianum i.e. for 150 days in a substrate of mixture of de-oiled cakes of neem, jatropha, mahua and karanjaes with sorghum grains and wheat bran. Several workers also reported that neem cake encouraged the saprophytic soil microflora especially Trichoderma in coconut basins. 
Assessment of Trichoderma spp population in neem cake

To test the population built-up of Trichoderma spp. under in vitro conditions, the effective bioagents were mixed with sterilized and unsterilized neemcake separately and heaped for different days. The population of bioagents was assessed at 10 , 20, 30, 40, 50 and 60 days interval and the results showed that 20 days incubation period buildup good population of Trichoderma spp. in both sterilized and unsterilized neem cake.
Maximum number of colonies of Trichoderma spp was observed more in sterilized neem cake than unsterilized neem cake (Table 2). The results were on par with the findings of Bhaskaran (1990), who reported that T.harzianum and T.hamatum were found to be antagonistic to G.lucidum and application of neem cake (5 or $10 \mathrm{~kg} /$ palm / year) encouraged the saprophytic soil micro flora especially Trichoderma in coconut basins and was effective in the control of Ganoderma wilt.

Table.1 Substrate for mass multiplication of Trichoderma spp

\begin{tabular}{|l|c|c|c|}
\hline \multirow{2}{*}{ Substrate } & \multicolumn{3}{|c|}{ Mycelial growth (after 7 days) } \\
\hline 30\% neem cake & T.viride & T.harzianum & T.hamatum \\
\hline 7\% neem cake & +++ & +++ & +++ \\
\hline Farmyard manure & +++ & +++ & +++ \\
\hline Coconut coir & ++ & ++ & ++ \\
\hline Coconut dry leaf powder & -- & -- & -- \\
\hline Coconut fresh leaf bits & -- & -- & -- \\
\hline Oil palm stem bits & ++ & ++ & ++ \\
\hline Oil palm leaf bits & +++ & +++ & +++ \\
\hline Wheat grains & +++ & +++ & +++ \\
\hline Bengal gram & +++ & +++ & +++ \\
\hline Red gram & ++ & ++ & ++ \\
\hline Bajra & + & + & + \\
\hline
\end{tabular}

-- No growth; + Slight growth; ++ Moderate growth; +++ Maximum growth

Table.2 Population load of biocontrol agents in neem cake under sterilized and unsterilized conditions

\begin{tabular}{|c|c|c|c|c|c|c|c|c|c|c|c|c|}
\hline \multirow[t]{3}{*}{ Isolate } & \multicolumn{6}{|c|}{$\begin{array}{l}\text { Neem cake unsterilized } \\
\left(\mathrm{Cfu} \times \mathbf{1 0}^{-4}\right)\end{array}$} & \multicolumn{6}{|c|}{$\begin{array}{c}\text { Neem cake sterilized } \\
\left(\text { Cfu x 10 } \text { 10 }^{-4}\right)\end{array}$} \\
\hline & \multicolumn{12}{|c|}{ Day's intervals } \\
\hline & 10 & 20 & 30 & 40 & 50 & 60 & 10 & 20 & 30 & 40 & 50 & 50 \\
\hline T.viride & 4 & 31 & 22 & 9 & 5 & 2 & 20 & 48 & 43 & 29 & 17 & 11 \\
\hline T.harzianum & 5 & 28 & 24 & 8 & 6 & 0 & 19 & 44 & 37 & 26 & 20 & 10 \\
\hline T.hamatun & 7 & 32 & 22 & 10 & 5 & 2 & 23 & 51 & 42 & 31 & 26 & 14 \\
\hline
\end{tabular}


Table.3 Field efficacy of Trichoderma spp on stem bleeding disease in coconut

\begin{tabular}{|c|c|c|c|c|}
\hline \multirow{2}{*}{\multicolumn{2}{|c|}{ Treatments }} & \multicolumn{3}{|c|}{ Perimeter of the exudation patch $(\mathrm{cm})$} \\
\hline & & Initial & Final & Decrease/Increase \\
\hline $\mathrm{T}_{1}$ & $\begin{array}{l}\text { Basal application of } T \text {. viride }(50 \mathrm{~g})+\text { neem cake } \\
(5 \mathrm{~kg} / \mathrm{palm})\end{array}$ & 8.11 & 2.22 & -5.88 \\
\hline $\mathrm{T}_{2}$ & $\begin{array}{l}\text { Basal application of } T \text {. harzianum }(50 \mathrm{~g})+\text { neem } \\
\text { cake( } 5 \mathrm{~kg} / \text { palm })\end{array}$ & 8.70 & 3.88 & -4.88 \\
\hline$T_{3}$ & $\begin{array}{l}\text { Basal application of } T \text {. hamatum }(50 \mathrm{~g})+\text { neem } \\
\text { cake }(5 \mathrm{~kg} / \text { palm })\end{array}$ & 6.22 & 2.77 & -3.44 \\
\hline $\mathrm{T}_{4}$ & $\begin{array}{l}\text { Smearing of talc formulation of T.viride paste on stem } \\
\text { bleeding patches }\end{array}$ & 8.22 & 0.77 & -7.44 \\
\hline $\mathrm{T}_{5}$ & $\begin{array}{l}\text { Smearing of talc formulation of T.harzianum paste on } \\
\text { stem bleeding patches }\end{array}$ & 7.77 & 0.22 & -7.55 \\
\hline $\mathrm{T}_{6}$ & $\begin{array}{l}\text { Smearing of talc formulation of T.hamatum paste on } \\
\text { stem bleeding patches }\end{array}$ & 8.22 & 4.77 & -3.44 \\
\hline $\mathrm{T}_{7}$ & $\begin{array}{l}\text { Basal application of } T \text {. viride }(50 \mathrm{~g})+\text { neemcake } \\
(5 \mathrm{~kg} / \mathrm{palm})+\text { Smearing of talc formulation of } T \text {.viride } \\
\text { paste on stem bleeding patches }\end{array}$ & 14.77 & 3.22 & -11.55 \\
\hline $\mathrm{T}_{8}$ & $\begin{array}{l}\text { Basal application of } T \text {. harzianum }(50 \mathrm{~g})+\text { neem } \\
\text { cake }(5 \mathrm{~kg} / \mathrm{palm})+\text { Smearing of talc formulation of } \\
\text { T.harzianum paste on stem bleeding patches }\end{array}$ & 15.77 & 2.66 & -13.11 \\
\hline $\mathrm{T}_{9}$ & $\begin{array}{l}\text { Basal application of } T \text {. hamatum }(50 \mathrm{~g})+\text { neem } \\
\text { cake }(5 \mathrm{~kg} / \mathrm{palm})+\text { Smearing of talc formulation of } \\
\text { T.hamatum paste on stem bleeding patches }\end{array}$ & 13.84 & 5.33 & -8.51 \\
\hline $\mathrm{T}_{10}$ & Neem cake $5 \mathrm{~kg} /$ palm/year & 12.26 & 4.0 & -2.26 \\
\hline $\mathrm{T}_{11}$ & Untreated control & 5.68 & 8.36 & +2.68 \\
\hline \multicolumn{4}{|c|}{$\mathrm{CD}(\mathrm{p}=\mathbf{0 . 0 5})$} & 1.32 \\
\hline
\end{tabular}

Fig.1 In vitro antagonism of native fungal and bacterial agents on coconut stem bleeding pathogen

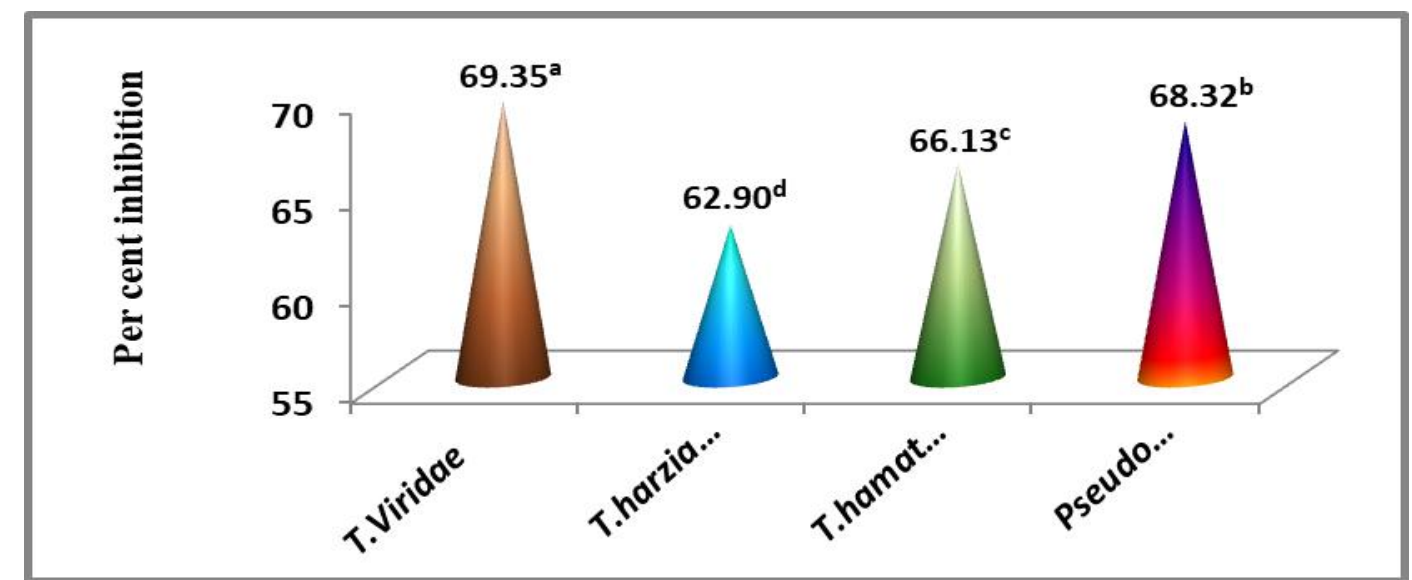

* Numbers in each column followed by the different letter are significantly different. Values represent the means of 6 replicates. 
Plate.1 Stem bleeding patch on the trunk of coconut palm
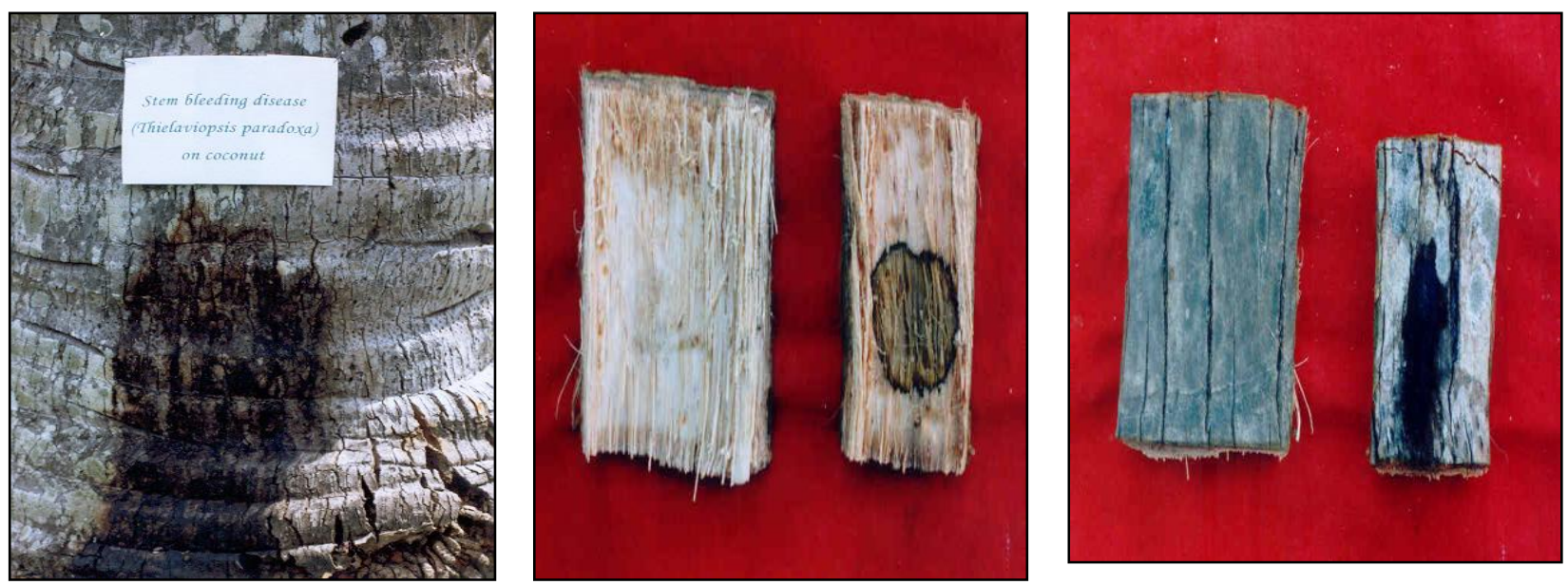

Plate.2 Stem bleeding disease pathogen

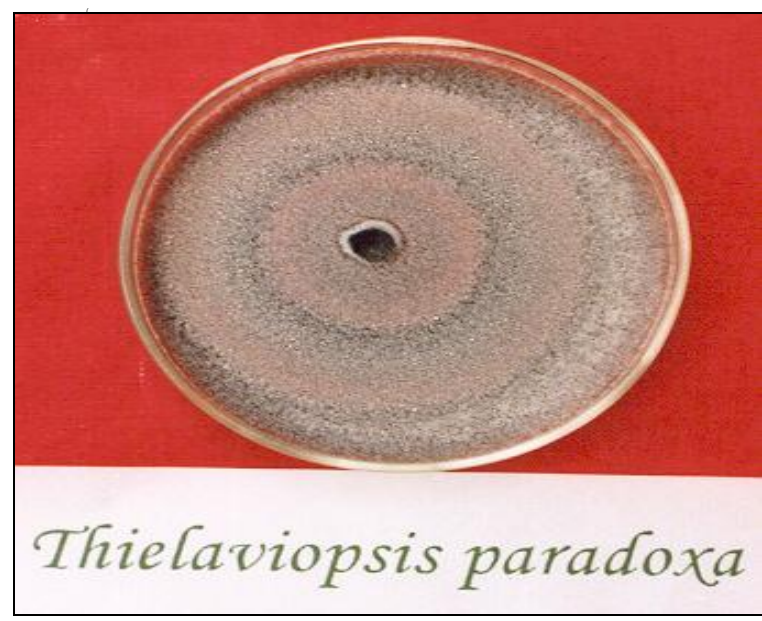

Plate.3a In-vitro efficacy of Trichoderma spp on $T$. paradoxa

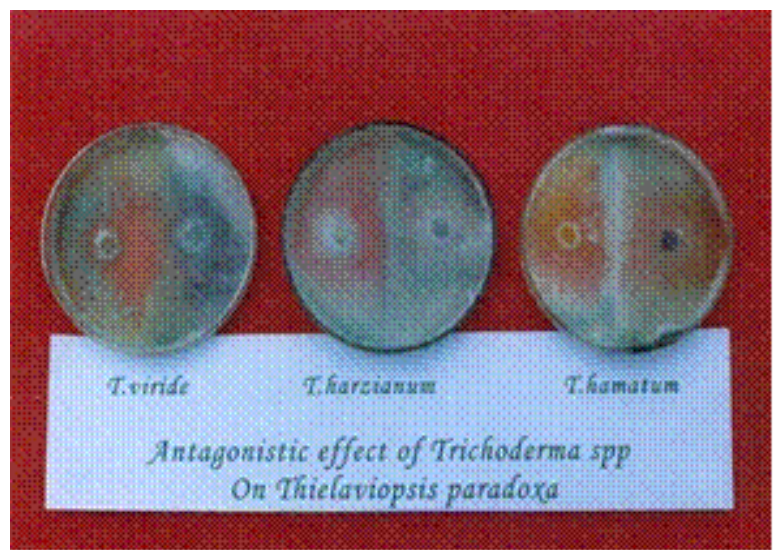

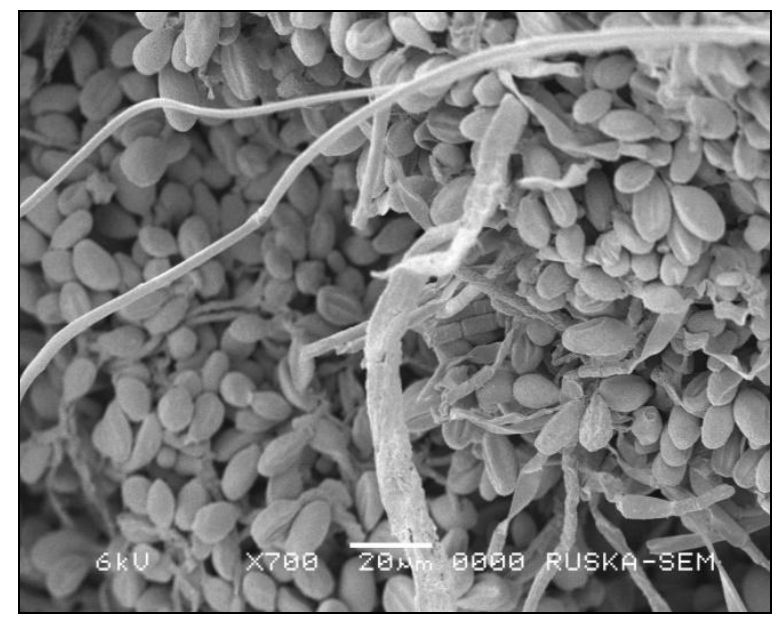

Plate.3b In-vitro efficacy of P.fluorescens on $T$. paradoxa

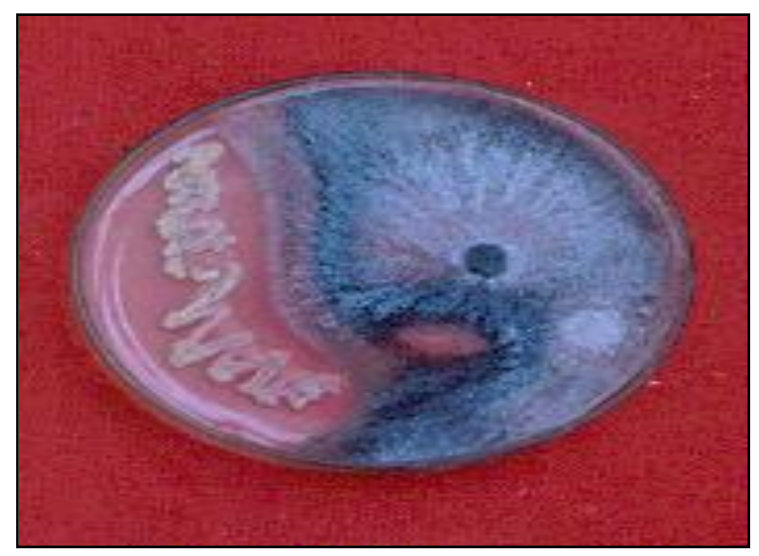



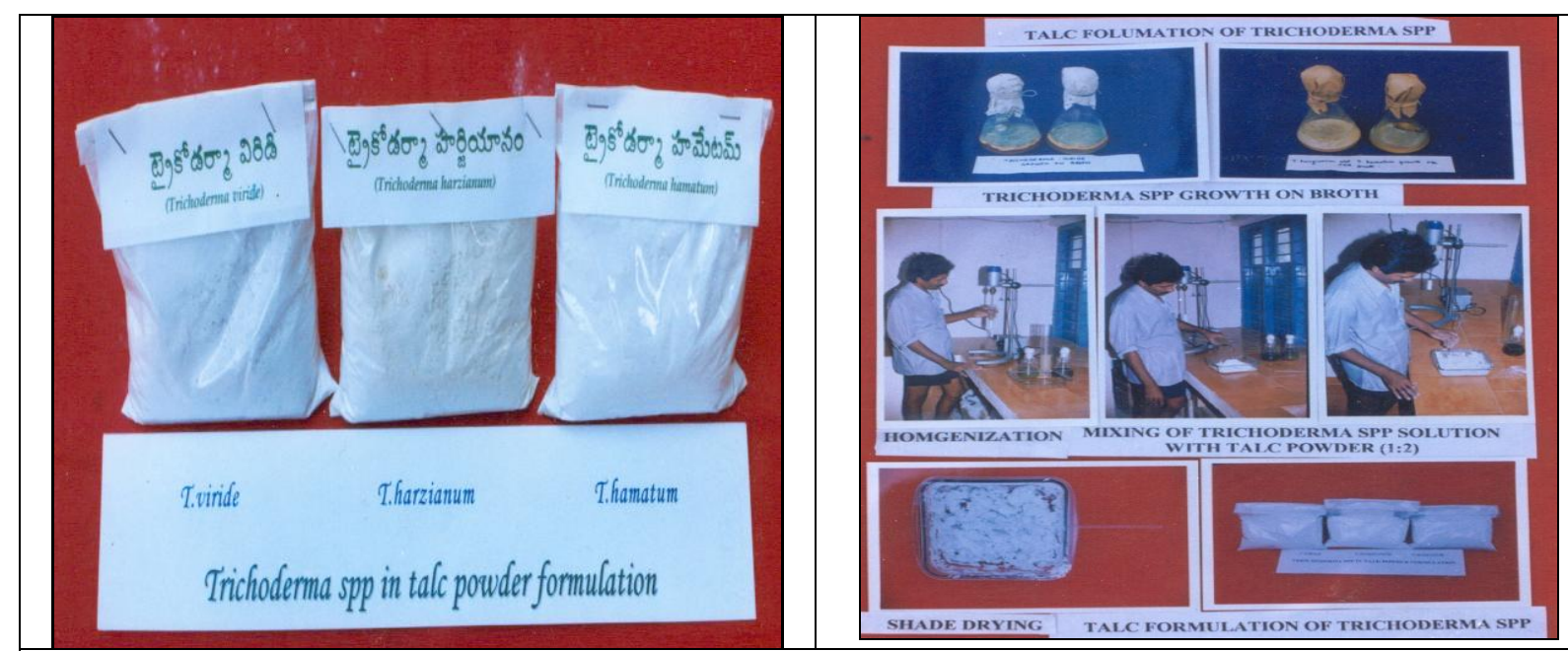

Plate.4 Talc formulation of Trichoderma spp.
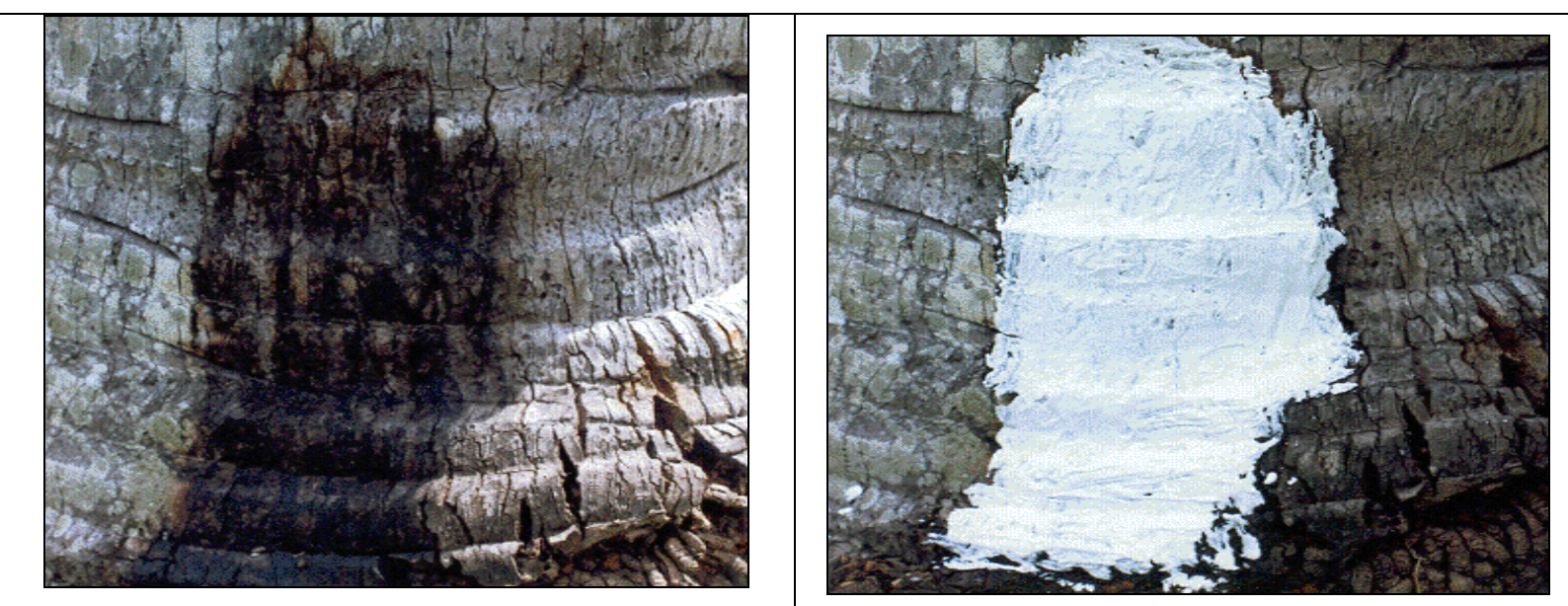

Plate.5 Smearing of talc formulation of T.viride paste on stem bleeding patches
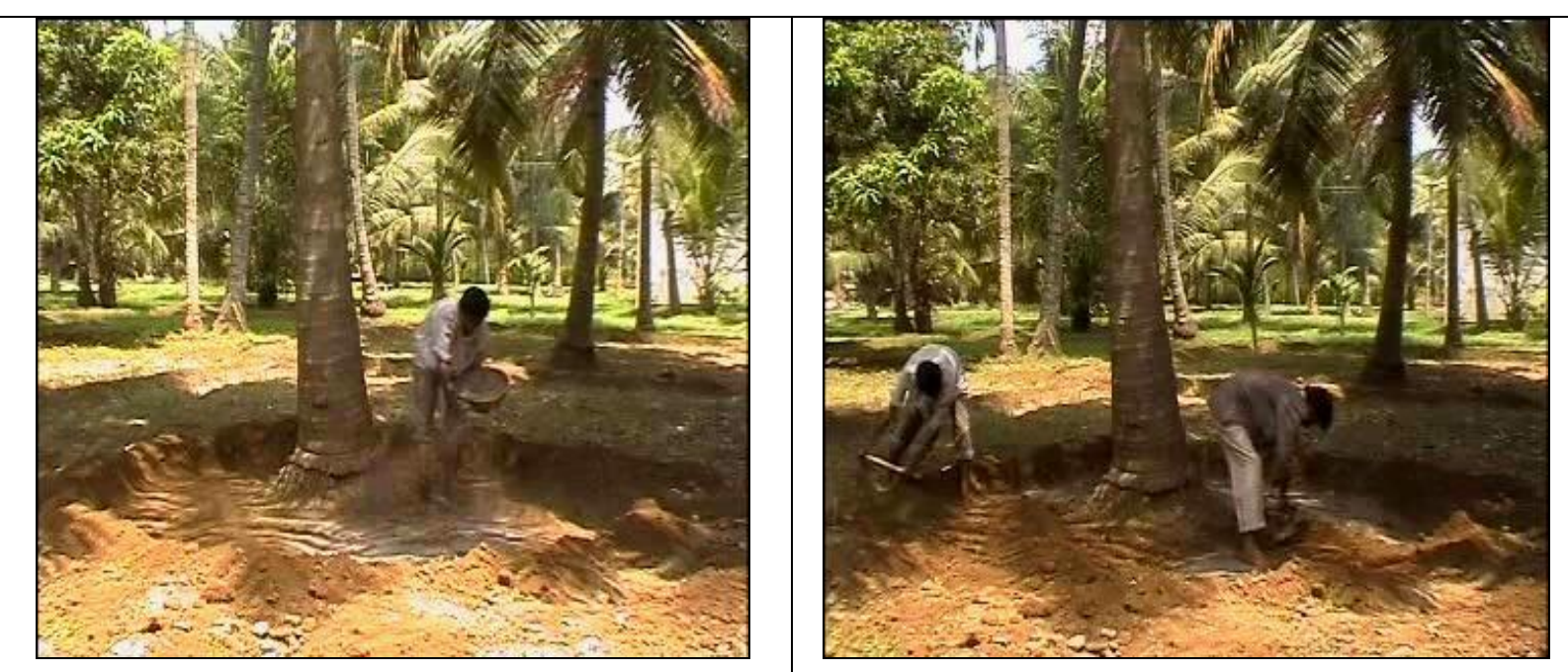

Plate.5 Basal application of T. viride $(50 \mathrm{~g})+$ Neemcake $(5 \mathrm{~kg}) /$ year 
Field efficacy of native bioagents on coconut stem bleeding pathogen Thielaviopsis paradoxa

The results of the field experiment indicated that all three Trichoderma spp were effective against stem bleeding disease. It was observed from the table 3 and plate $4 \& 5$, that there was decrease of perimeter of the exudation patch $(\mathrm{cm})$ in all the treatments except in $\mathrm{T}_{11^{-}}$ untreated control where the perimeter of the exudation patch increased by $2.68 \mathrm{~cm}$. The reduction of exudation patch $(\mathrm{cm})$ ranged from minimum of $2.26 \mathrm{~cm}$ with $\mathrm{T}_{10}$ treatment i.e., application of neem cake @ 5kg/pal/year) to maximum of $13.11 \mathrm{~cm}$ with $\mathrm{T}_{8}$ treatment i.e., basal application of $T$. harzianum $(50 \mathrm{~g})+$ neem cake $(5 \mathrm{~kg}) /$ year + smearing of talc formulation of T.harzianum paste on stem bleeding patches).Among the different treatments imposed, maximum decrease in bleeding patch $(13.11 \mathrm{~cm})$ was obtained with $\mathrm{T}_{8}$ i.e., basal application of $T$. harzianum (50 g) + neemcake $(5 \mathrm{~kg}) /$ year $)+$ smearing of talc formulation of $T$. harzianum paste on stem bleeding patches) closely followed by $\mathrm{T}_{7}$ treatment $(11.55 \mathrm{~cm})$ i.e., basal application of T. viride $(50 \mathrm{~g})+$ neemcake $(5 \mathrm{~kg}) /$ year $)+$ smearing of talc formulation of $T$. viride paste on stem bleeding patches) and $T_{9}$ treatment i.e., basal application of T.hamatum $(50 \mathrm{~g})+$ neemcake $(5 \mathrm{~kg}) /$ year $)+$ smearing of talc formulation of T.hamatum paste on stem bleeding patches) with a reduction in perimeter by $11.55 \mathrm{~cm}$ and $8.51 \mathrm{~cm}$ respectively. The results were in tune with the finding of Srinivasulu and Raghava Rao (2009), who reported that the application of Trichoderma spp. caused lysis of mycelium of Ganoderma lucidum. Furthermore, they have found that the application of T. harzianum/T. viride/T. hamatum pasted over bleeding patches and soil application of the bioagents @ $50 \mathrm{~g}$ in $5 \mathrm{~kg}$ neem cake has reduced the perimeter of the Ganoderma wilt patches on coconut trees.
Neeraja et al., (2018) soil application of talc based formulation of $125 \mathrm{~g}$ each of Trichoderma reesei and Pseudomonas fluorescens $+5 \mathrm{~kg}$ of neemcake/palm at yearly interval was effective in managing the Basal stem rot disease (Ganoderma wilt). Soil application of $125 \mathrm{~g}$ of each Trichoderma reesei and Pseudomonas sp along with neem cake $5 \mathrm{~kg}$ per palm per year reduced the disease incidence and increased the nut yield of coconut (Manjunath et al., 2019).

In the present study, the decrease of bleeding patches was observed and the reason attributed may be when the biocontrol agents applied to the bleeding patches, they established on the rotted region at the expense of the pathogen and sporulate there by caused amelioration of the tissue from further rotting by the stem bleeding pathogen Thielaviopsis paradoxa. Trichoderma spp had shown inhibitory effect on stem bleeding disease pathogen Thielaviopsis paradoxa by production of volatile and non-volatile metabolites that are antagonistic to the pathogen besides mycoparasitism. Soil application of Trichoderma spp along with neem cake favours the population built up of Trichoderma spp. in the soil, thereby causing reduction in the Thielaviopsis paradoxa population and subsequently the disease spread. This is evident from the fact that all the treated palms have contained only one spot and no further appearance of the bleeding patches except in control palms where the number of bleeding patches increased from 1 to 4 minute specks. The reason attributed may be the treatments containing Trichoderma spp either by smearing of Trichoderma spp. paste on stem bleeding patches along with soil application with neem cake was effective in controlling the further spread of the disease. Neem cake is suitable substrate for multiplication of Trichoderma spp (Srinivasulu et al., 2004a) and is also inhibitory to the growth of T.paradoxa 
(Ramanujam et al., 2002). However, neem cake when applied alone was effective in checking the inoculums load of Thielaviopsis paradoxa in an indirect way probably through increasing the population load of the existing antagonistic mycoflora thereby preventing the further spread of the diseased perimeter of the bleeding patch. On the other hand, control palms recorded an increase in the disease severity as indicated by an increase in perimeter of the bleeding patch. The results of the fields experiment offer a scope for an easy and effective management of the stem bleeding disease at field level by the coconut farmers.

It is concluded that in nutshell, native biocontrol agents viz., Trichoderma viridae, Trichoderma.hamatum and Trichoderma harzianum screened for antagonism under in vitro are effective against mycelia growth of stem bleeding pathogen Thielaviopsis paradoxa. Under field conditions, basal application of T.harzianum (50 g) or Trichoderma viridae (50g) with neem cake $(5 \mathrm{~kg} / \mathrm{palm})$ in combination with smearing of talc formulation of Trichoderma harzianum or Trichoderma viridae paste on stem bleeding patches were effective in controlling the stem bleeding of coconut.

\section{References}

Ajay Tomer, Ramji Singh, Prashant Singh. 2016.Suitability of de-oiled cakes of neem, jatropha, mahua and karanja along with cereals and millets substrates for mass multiplication of Trichoderma harzianum.Academy of Agriculture Journal 1: 2 pp. $23-27$.

Bhaskaran, R. 1990. Biological control of Thanjavur wilt disease of coconut. National Symposium on Biocontrol of Root Diseases. Annamalai University. Annamalainagar (Abstr.) pp 7-8.

Darmono, T. W., Purwantara, A. 2006. Large scale application of growth promoting Tricnoderma with biofugicidal activity. $9^{\text {th }} \quad$ International workshop on Trichoderma and Gliocladium book of abstracts Vienna University of Technology April 6-8, Vienn, Austria.

Denis, C. and Webster. J. 1971. Antagonistic properties of species growth of Trichoderma-III. Hyphal interaction. Trans Br.Mycol. Soc., 57:363-369.

Elad, Y., Chet, I., Boyle, P. and Henis, Y., 1983 Parasitism of Trichoderma spp on Rhizoctonia solani and Sclerotium rolfsii - scanning electron microscopy and fluorescence microscopy. Phytopathology, 73: 418-422

Gams, W., H.A. Vander A.A., A.J. Vander Plaats-Niterink, R.A.Samson and J.A. Stalpers. 1980. CBS Course of Mycology, second edition. Centra albureau voor Schimmelcultures. Baarn, The Nethelands.

George P, Gupta A, Gopal M, Chandra Mohanan R, Thomas L and Thomas G V. 2012. In vitro antagonism of rhizospheric fluorescent pseudomonads of coconut against Ganoderma applanatum and Thielaviopsis paradoxa, fungal pathogens of coconut. Journal of Plantation Crops, 40(2): 7581.

Eziashi, E. I., Uma, N. U., Adekunle, C. E. and Odigie, E. E. 2010. Evaluation of lyophilized and non-lyophilized toxins from Trichoderma species for the control of Ceratocystis paradoxa. African Journal of Agricultural Research, 5, 13, 1733-1738.

Hildebrand, D.C., Schroth, M.N. and Sands, D.C. 1992. Pseudomonas. In. Schaad NW (ed) Laboratory Guide for identification of Plant pathogenic Bacteria, $2^{\text {nd }}$ edition, Americal Phytopathological Society. St. Paul, M.N. 
Hoitink, H. A. J., Madden, L.V., and Dorrance, A. E. 2006. Systemic resistance induced by Trichoderma spp.: Intractions between the host, the pathogen, the biocontrol agent, and soil organic matter quality. Phytopathol., 96:186-189.

Jayarajan, R., Ramakrishnan, G., Dinakaran, D. and Sridhar, R. 1994. Development of product of T.viride and Bacillus subtilis for biocontrol of root rot disease. pp. 25-36. In Dwivedi, B.K. (Ed), Biotech. in India. Bioved Research Society. Allahabad, India.

Karthikeyan, G., Karpagavalli, S., Rabindran, R. and Natarajan, C. 2005. Biological control of basal stem rot disease in coconut. The Planter, 81(957):777-784.

Manjunath Hubballi, HPMaheshwarappa, R Siddappa and GS Chandrashekar. 2019. Biological control agents for the management of Basal stem rot disease in coconut. J Mycol Pl Pathol, Vol. 49, No. 1. pp:89-97

Mohiddin. F.A., Imran Bashir, Shahid, A. Padder and Burhan Hamid.2017. Evaluation of different substrates for mass multiplication of Trichoderma species .Journal of Pharmacognosy and Phytochemistry . 6(6): 563-569

Nambiar, K.K.N. 1994. Diseases and disorders of coconuts. In: Advances in Horticulture vol. 10 Plantation and Spice Crops Part 2. K.L. Chadha and P. Rethinam, (Eds.). Malhotra Publishing House, New Delhi., pp-857-882

Nandakumar, R., Babu, S., Viswanathan, R., Raguchander, T. and Samiyappan, R. 2000. Induction of systemic resistance in rice against sheath blight disease by Pseudomonas fluorescens. Soil Biol. Biochem.

Neeraja, B., Snehalatharani, A., Maheswarappa, H.P., Ramanandam, G., ChalapathiRao, N.B.V. and Padma, E. 2018. Management of basal stem rot
(Ganoderma Wilt) in coconut with effective bioagents under field condition. Int.J.Curr.Microbiol.App.Sci. 7(9): 1051-1060

Petch, T. 1906, Diseases of the coconut palm. Trop. Agriculturist. 27:490-491.

Priya George, Alka G, Murali Gopal, R Chandra Mohanan, Litty Thomas and George V. 2012. In vitro antagonism of rhizospheric fluorescent pseudomonads of coconut against gnanoderma applanatum Thielaviopsis paradoxa fungal pathogens of coconut. $\mathbf{J}$ Plantation Crops 40: 75-81.

Radhakrishnan, T.C.1990, Control of stem bleeding disease of coconut. Indian Coconut J. 20(9):13-14.

Ramamoorthy V, Raguchander $\mathrm{T}$ and Samiyappan R 2002. Enhancing resistance of tomato and hot pepper to diseases by seed treatment with fluorescent pseudomonads. 108: 429441.

Ramanujam, B., Nambiar, K.K.N. and Anil Kumar. 1993. Chemical control of stem bleeding disease of coconut. In: Advances in coconut Research and Development, (Eds.) M.K. Nair, H.H. Khan, P. Gopalasundaram and E.V.V.B. Rao Oxford and IBH publishing Co. Pvt. Ltd., New Delhi., pp- 615-616.

Rani, C.R and Sulochana, K.K. 2007. Substrate evaluation for multiplication of Trichoderma spp. Journal of Tropical Agriculture. 45(1): 58-60

Ranjana chakrabarty, G.C. Acharya and T.C. Sarma, 2013, Effect of Fungicides, Trichoderma and Plant extracts on mycelial growth of Thielviopsis paradoxa, under in vitro condition. The Bioscan. 8(1): 55-58.

Sanchez, V., Rebolledo, O., Picaso, R. M., Cardenas, E., Cordova, J. and Samuels, G.J. 2007. In vitro antagonism of Theieloviopsis paradoxa by 
Trichoderma longibrachiatu. Mycopathologia, 163, 49-58.

Saravanakumar D, Lavanya N, Muthumeena B, Raguchander T, Suresh S and Samiyappan R.2008. Pseudomonas fluorescences enhance resistance and natural enemy population in rice plants against leaf folder pest. 132:469-479.

Srinivasulu, B. and Raghava Rao, D. V. (2009). Biocontrol of major diseases of coonut. In: P. Ponmurugan, and M. A. Deepa (eds): Role of Biocontrol Agents for Disease Management in Sustainable Agriculture. SCITECH (India) Pvt., Chennai pp. 352-368.

Srinivasulu B, Kumar KVK, Aruna K and Rao DVR. 2005. Biocontrol of basal stem rot Gnanoderma wilt) disease of coconut. II, AICRP on Palms, ARS, Ambajipeta, ANGRAU

Sundraraman, s. 1922. The coconut bleeding disease. Pusa Agr. Res. Inst. Bull. 127: $8 \mathrm{p}$

Sudarshan, G.K., Chandrashekara, G.S., Basavaraju, T.B., Palanna, K.B. and Mutthuraju, G.P. 2019. Evaluation of botanicals, bio agents and fungicides against stem bleeding of coconut caused by thielviopsis paradoxa under in vitro conditions. Int.J.Curr.Microbiol.App. Sci. 8(2): 2690-2695.

Tapwal, A., Singh, U., De Silva, J. A. T. Singh, G., Garg, S. and Kumar, R. 2011. In vitro antagonism of Trichoderma viride against five phytopathogens. Pest technology 5 (1), 59-62.

Vincent J. M. (1947). Distortion of fungal hyphae in the presence of certain inhibitors. Nature 159: 850

\section{How to cite this article:}

Aruna, K. and Kalpana Motha. 2020. In vitro and Field Efficacy of Native Biocontrol Agents on Stem Bleeding Pathogen of Coconut Thielaviopsis paradoxa. Int.J.Curr.Microbiol.App.Sci. 9(03): 2342-2354. doi: https://doi.org/10.20546/ijcmas.2020.903.267 